
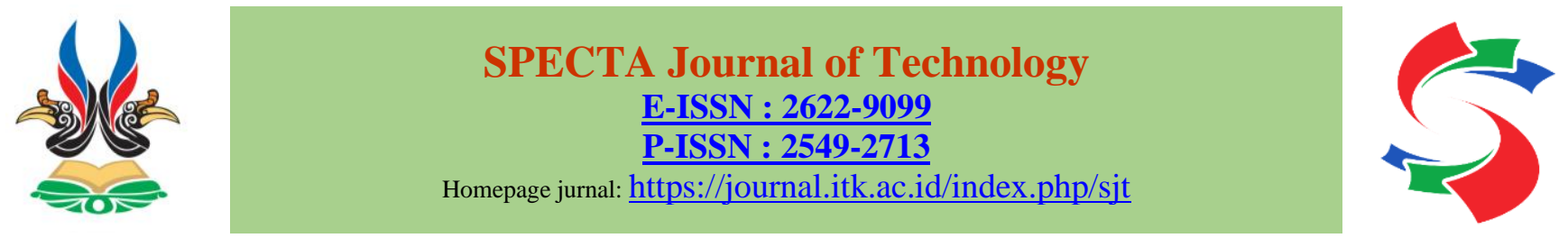

\title{
Karakteristik Buah Nipah Karbon Aktif dari Serabut Nipah Teraktivasi Potassium Hydroxide (KOH)
}

\author{
Ade Wahyu Yusariarta Putra ParmitaI, Andromeda Dwi Laksono², Muhammad Iskandar \\ Zulkarnain ${ }^{3}$, Ansita Fitri Budi Hartanti, Rizky Vi'atul Mudhawammah ${ }^{5}$ \\ 1,2,3,4,5 Program Studi Teknik Material dan Matalurgi, Jurusan Ilmu Kebumian dan Lingkungan, Institut \\ Teknologi Kalimantan, Balikpapan. Email: adewahyu27@lecturer.itk.ac.id
}

\begin{abstract}
Nipa or mangrove palm waste can be source of activated carbon by chemical activation method using potassium hydroxide $(\mathrm{KOH})$. Nipa palm fiber was carburized at $400^{\circ} \mathrm{C}$ and activated by $1.5 \mathrm{M} \mathrm{KOH}$. The results of $\mathrm{KOH}$ activation are compared with the results from carbonization. The physical and microstructural properties of nipa activated carbon were characterized by X-ray diffractometer (XRD), scanning electron microscope (SEM), Fourier Transform Infrared (FTIR). There are still functional groups that indicate lignocellulose and graphite from both carbunization and activated by $1.5 \mathrm{M} \mathrm{KOH}$ but the hydroxyl group was decrease when activated by $\mathrm{KOH}$. The nipa activated carbon that activated by $1.5 \mathrm{M} \mathrm{KOH}$ have the graphite amorphous while the carbonization results produce more crystalline graphite. There was no impurity on nipa activated carbon that activated by $1.5 \mathrm{KOH}$. Morphological results showed that the porous size of $\mathrm{KOH}$ activated carbon was $8.8 \%$ greater than without chemical activation. A larger pore size will indicate a higher surface area, so it will be good for adsorbent material.
\end{abstract}

Keywords: Activated Carbon, Carbonization, Chemical Activation, Nipa Palm Fiber, Potassium Hydroxide.

\begin{abstract}
Abstrak
Karbon aktif yang bersumber dari serabut buah nipah yang merupakan limbah yang belum dimanfaatkan dengan maksimal dibuat menggunakan metode aktivasi secara kimia menggunakan potassium hydroxide (KOH). Proses pembuatan karbon aktif dimulai dengan proses karbonisasi dilakukan dengan temperatur $400^{\circ} \mathrm{C}$ kemudian diaktivasi dengan kosentrasi KOH 1,5M. Hasil aktivasi KOH dibandingkan dengan hasil dari karbonisasi. Diperoleh hasil secara FTIR yang menunjukkan masih terdapat gugus fungsi yang menunjuukan adanya lignoselulosa dan sudah terbentuk grafit. Hasil XRD juga menunjuukan terbentuknya graphite amorph pada hasil aktivasi dengan $\mathrm{KOH}$ sedangkan hasil karbonisasi menghasilkan grafit yang lebih kristalin. Hasil XRD juga menunjukkan pada aktifasi KOH sudah tidak ada pengotor yang mengindikasikan proses adsorpsi yang lebih baik dibandingkan tanpa aktivasi. Hasil morfologi menunjukkan ukuran poros pada karbon yang teraktivasi KOH lebih besar 8,8 \% dari pada tanpa aktivasi secara kimia. Ukuran pori yang lebih besar akan mengindikasikan luas permukaan yang lebih luas, sehingga akan lebih baik digunakan sebagai adsorben.
\end{abstract}

Kata Kunci: Aktivasi secara Kimia, Karbonisasi, Karbon Aktif, Potassium Hydoxide, Serabut Buah Nipah.

\section{Pendahuluan}

Pohon nipah atau Nypa fruticans merupakan salah satu pohon yang memiliki famili yang sama dengan kelapa yaitu famili Arecaceae. Nypa fruticans atau dikenal sebagai nipah, adalah spesies asli pohon palem yang tumbuh di pesisir pantai dan muara di Samudera Hindia dan Pasifik. Adapun luasan nipah di Indonesia meliputi 700,000 hektar (Kelola Sendang, 2017). Berdasarkan laporan dari Heriyanto, 2011 
yang meneliti tentang sebaran tanaman nipah di Desa Bengalon, Kecamatan Bengalon, Kabupaten Kutai Timur, Provinsi Kalimantan Timur pada bulan Oktober 2010, diperolah hasil yaitu pohon nipah atau Nypa fruticans dapat berbuah dengan rata-rata 3,55 bonggol/pohon 2,83 bonggol buah nipah tua dan 0,76 bonggol buah nipah muda/pohon, setiap bonggol rata-rata berisi 65 buah nipah, jumlah buah nipah dalam 1 ha rata-rata 196.120 buah. Buah nipah pada umumnya dimanfaatkan untuk kolang kaling, bagian yang digunakan untuk kolang kaling yaitu daging buah nipah, sedangkan kulit buah nipah jarang yang memanfaatkan, sehingga sering dibuang dan menjadi limbah. Kulit buah nipah mengandung unsur lignoselulosa yang tinggi mencapai 87,1 \% dan sangat baik digunakan sebagai sumber karbon untuk pembuatan karbon aktif (Tamunaidu, 2011).

Salah cara untuk menjadikan lignoselulosa menjadi karbon aktif yaitu karbonisasi (Gercia,2017). Karbonisasi merupakan proses pembakaran benda organik dengan temperatur $400-600^{\circ} \mathrm{C}$. Proses karbunisasi pada temperatur tersebut akan menghasilkan baberapa pengotor seperti tar. Untuk menghilangkan tar bisa dengan cara menaikan temperaur diatas $600^{\circ} \mathrm{C}$ serta dalam kondisi vakum atau dengan larutan kimia seperti potassium hydroxide $(\mathrm{KOH})$, acid chloride $(\mathrm{HCl})$, dan natrium hydroxide $(\mathrm{NaCl})$ (Hassler, 1951). Proses penambahan larutan kimia sering disebut dengan aktivasi secara kimia. Tujuan dari aktivasi secara kimia yaitu untuk memutus rantai karbon dari senyawa organik dengan menggunakan bahan-bahan kimia seperti $\mathrm{H}_{3} \mathrm{PO}_{4}, \mathrm{H}_{2} \mathrm{SO}_{4}, \mathrm{HNO}_{3}, \mathrm{ZnCl}_{2}, \mathrm{NaOH}$, atau KOH. Kelemahan menggunakan aktivasi secara kimia, yaitu pada proses penetralan $\mathrm{pH}$ karbon yang telah diaktivasi (Jankowska, 1991). Kelebihan dari proses aktivasi secara kimia yaitu waktu yang digunakan untuk aktivasi relatif lebih cepat. Luas permukaan karbon aktif yang diperoleh dari aktivasi secara kimia lebih luas sehingga akan meningkatkan daya adsorpsinya. Fungsi lain aktivasi secara kimia yaitu untuk mendegradasi senyawa organik selama proses aktivasi, membatasi pembentukan tar, membantu dekomposisi senyawa organik, dihidrasi air yang terjebak dalam rongga-rongga karbon, membantu menghilangkan endapan hidrokarbon yang dihasilkan saat proses karbonisasi dan melindungi permukaan karbon sehingga kemungkinan terjadinya oksidasi dapat berkurang (Manocha, 2003).

Pada penelitian yang dilakukan Teng (1999) Proses aktivasi menggunakan larutan aktivasi Kalium Hidroksida $(\mathrm{KOH})$ menghasilkan karbon aktif dengan luas permukaan $3000 \mathrm{~m}^{2} / \mathrm{g}$ dan hasilnya juga menunjukkan bahwa struktur berpori yang terbentuk dari aktivasi $\mathrm{KOH}$ lebih stabil secara termal dibandingkan dengan aktivasi $\mathrm{H}_{3} \mathrm{PO}_{4}$ atau $\mathrm{ZnCl}_{2}$ (Teng, 1999). Menurut Wang (2012), aktivasi kimia dengan menggunakan $\mathrm{KOH}$ sangat menjanjikan dikarenakan aktivasi pada temperatur yang rendah namun mendapatkan hasil yang tinggi. Selain itu, ukuran mikropori terdistribusi dengan baik dan luas permukaan spesifik sangat tinggi hingga $3000 \mathrm{~m}^{2} / \mathrm{g}$. Dari hasil penelitian tersebut, maka $\mathrm{KOH}$ merupakan salah satu larutan aktivator yang baik untuk digunakan pada pembuatan karbon aktif (Hui, 2015).

Pada penelitian ini, akan dilakukan proses pembuatan karbon aktif dari serabut buah nipah dengan metoda aktivasi kimia menggunakan $\mathrm{KOH}$. Tujuannya yaitu untuk mengetahui perbedaan karakteristik secara gugus fungsi, struktur yang dihasilkan dan secara morfologi antara karbon aktif yang diaktivasi secara kimia dan tidak. Pada penelitian lebih lanjut, karbon berbahan dasar nipah dapat dikembangkan sebagai adsorbent untuk menjernihkan limbah cair yang terkontaminasi polutan organik.

\section{Metode}

\subsection{Alat dan Bahan}

Alat yang digunakan dalam penelitian ini antara lain: Fourier Transform Infrared (FTIR, Frontier Optica 96772 Perkin Elmer), X-Ray Diffraction (XRD, Bruker D8 Advance, Jerman) dengan CuKa, $\lambda=1,54$ dan pada sudut $2 \theta 10-90^{\circ}$, UV/vis spectrometer (Rayleigh UV-9200) dan Scanning Electron Microscopy (SEM, Hitachi S3000N Series) dengan voltase $10 \mathrm{kV}$.

Bahan yang digunakan dalam penelitian ini antara lain: serabut nipah yang bersumber dari muara badak Kalimantan timur, methylene blue (MB) merek smart Lab, KOH 85\% (Potassium Hydroxide) merek SAP dan air distilasi. 


\subsection{Prosedur Pembuatan Karbon Aktif}

Gambar 1 merupakan ilustrasi pembuatan karbon aktif. Pembuatan karbon aktif dimulai dengan tahap preparasi sampel arang dan $\mathrm{KOH}$ yang ditimbang sesuai perhitungan stoikiometri. Variabel yang ditetapkan adalah menggunakan perbandingan molaritas $\mathrm{KOH}$ (1,5 M) dan (0 M). Serabut nipah yang telah kering dikarbonisasi dengan temperatur $400^{\circ} \mathrm{C}$ selama 30 menit. Kemudian, arang yang telah jadi dihaluskan dan diayak dengan mortar dan ayakan 100 mesh. Setelah itu, arang dicampurkan dalam larutan $\mathrm{KOH} \mathrm{1,5} \mathrm{M} \mathrm{dengan} \mathrm{menggunakan} \mathrm{hotplate} \mathrm{stirrer} \mathrm{pada} \mathrm{temperatur} 85^{\circ} \mathrm{C}$ selama $2 \mathrm{jam}$. Selanjutnya, larutan disaring menggunakan kertas saring dan dibilas menggunakan air distilasi hingga $\mathrm{pH}$ sebesar 7. Kemudian, padatan dikeringkan dengan menggunakan oven pada temperatur $120^{\circ} \mathrm{C}$ selama 12 jam.

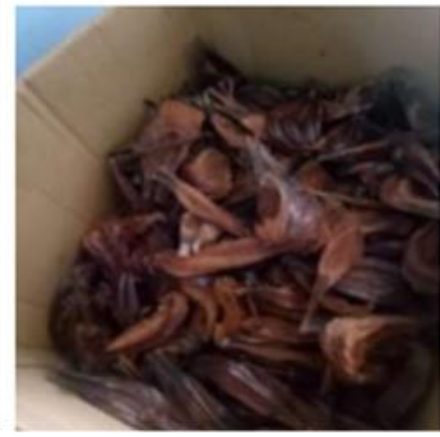

Serabut nipah yang telah dikeringkan

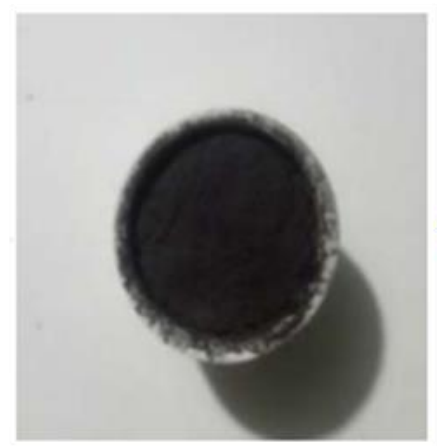

Arang teraktivasi $\mathrm{KOH}$

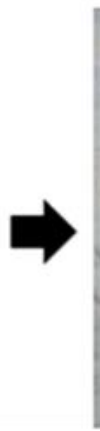

$$
\begin{aligned}
& \text { Karbonisasi } 400^{\circ} \mathrm{C} \text { selama } \\
& 30 \text { menit }
\end{aligned}
$$

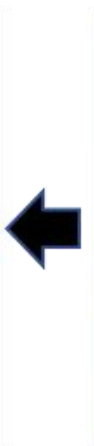

Arang- $\mathrm{KOH}$ dibilas hingga $\mathrm{pH} 7$

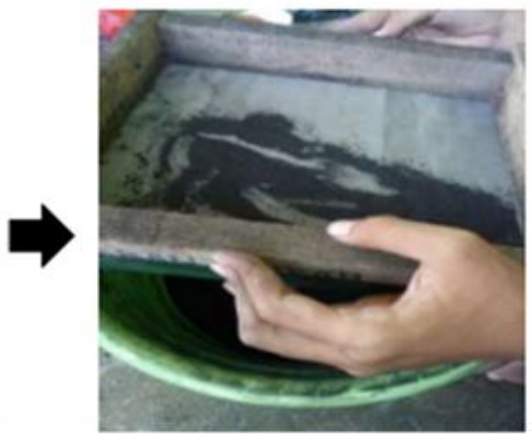

Arang diayak dengan saringan ukuran 100 mesh

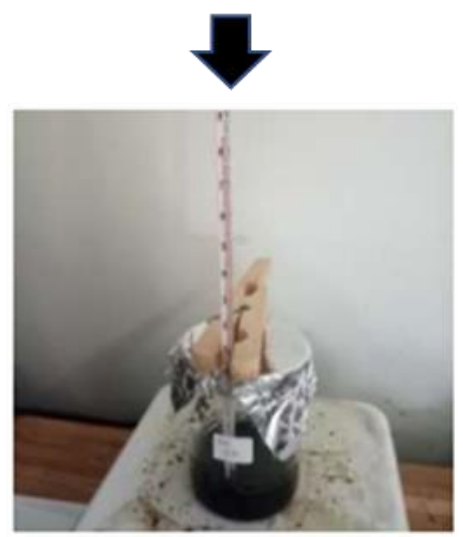

Arang dicampur dengan larutan $\mathrm{KOH}$ selama 2 jam pada temperature $85^{\circ} \mathrm{C}$

Gambar 1: Diagram Alir Pembuatan Karbon Aktif

\section{Hasil dan Pembahasan}

\subsection{Analisis (Fourier-Transform Infrared Spectroscopy) FTIR}

Pengujian FTIR dilakukan untuk mengetahui ikatan kimia dan gugus fungsi dari masing-masing sampel. Pada Gambar 2 menunjukkan gugus fungsi serabut nipah dan serabut nipah yang teraktivasi dengan KOH. Panjang gelombang 3100-3488 $\mathrm{cm}^{-1}$ merupakan vibrasi strectching O-H hydroxyl (Sun, 2010). Panjang gelombang $2920-2990 \mathrm{~cm}^{-1}$ merupakan vibrasi asymmetric C-H alkane. Panjang gelombang $2361 \mathrm{~cm}^{-1}$ merupakan vibrasi $\mathrm{C} \equiv \mathrm{C}$ alkynes (Foo, 2011). Panjang gelombang $1739 \mathrm{~cm}^{-1}$ menunjukkan vibrasi $\mathrm{C}=\mathrm{O}$ Carbonyl. Panjang gelombang $1430-1625 \mathrm{~cm}^{-1}$ terdapat vibrasi $\mathrm{C}=\mathrm{C}$ aromatic. Panjang gelombang 1310-1410 terdapat vibrasi O-H Tertiary Alcohol (George, 2001). Panjang gelombang 1220$1260 \mathrm{~cm}^{-1}$ merupakan vibrasi C-O aliphatic dan aromatic (Sreenivasan, 1996). Panjang gelombang 1054 $\mathrm{cm}^{-1}$ merupakan vibrasi stretching $\mathrm{C}-\mathrm{O}$ (Kartick, 2013). Pada Gambar 2 terdapat ikatan stretching $\mathrm{O}-\mathrm{H}$ 
gugus hydroxyl menurun pada karbon yang teraktivasi $\mathrm{KOH}$. Karbon yang teraktivasi dengan $\mathrm{KOH}$ akan mampu menghidrasi air yang terjebak dalam rongga-rongga karbon, ditandai dengan menurunnya gugus hydroxyl, sehingga endapan hidrokarbon yang dihasilkan saat proses karbonisasi akan menghilang. Hilangnya hidrokarbon akan manyebabkan permukaan permukaan karbon terlindungi sehingga kemungkinan terjadinya oksidasi dapat berkurang dan akan menghasilkan luas permukaan yang lebih besar (Manocha, 2003).

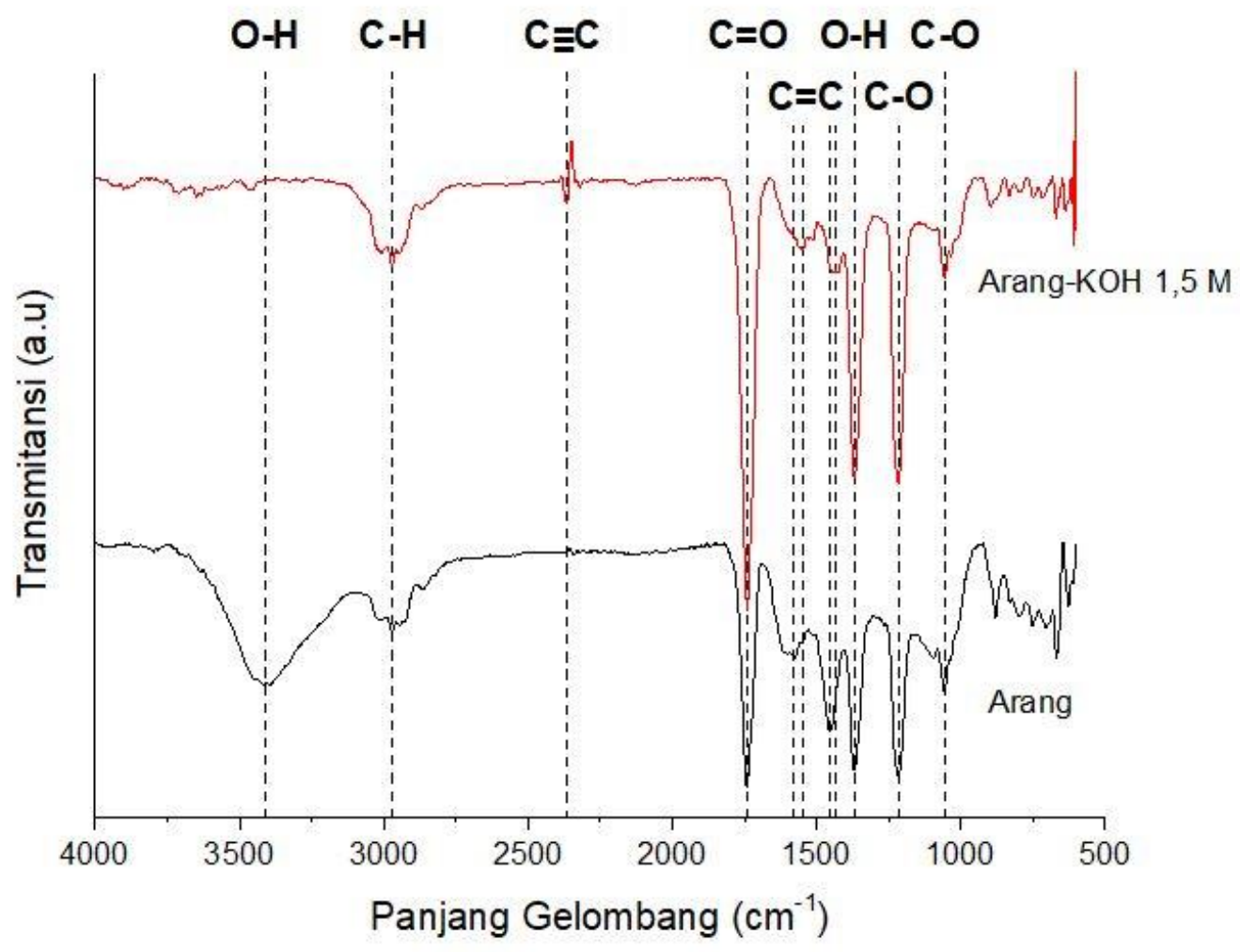

Gambar 2: Hasil Pengujian FTIR

Tabel 1: Komposisi inorganik nipah

\begin{tabular}{|c|c|c|c|c|}
\hline No & $\begin{array}{l}\text { Arang } \\
\left(\mathbf{c m}^{-1}\right)\end{array}$ & $\begin{array}{l}\text { Arang-KOH } \\
0,5 \mathrm{M}\left(\mathrm{cm}^{-1}\right)\end{array}$ & $\begin{array}{l}\text { Arang-KOH } \\
1,5 \mathrm{M}\left(\mathrm{cm}^{-1}\right)\end{array}$ & Gugus Fungsi \\
\hline 1 & 1369 & 1369 & 1369 & In-plane O-H Tertiary Alcohol \\
\hline 2 & $\begin{array}{l}1215 \\
1054\end{array}$ & $\begin{array}{l}1215 \\
1054\end{array}$ & $\begin{array}{l}1215 \\
1054\end{array}$ & C-O aliphatic dan aromatic \\
\hline 3 & $\begin{array}{l}1556 \\
1452\end{array}$ & $\begin{array}{l}1556 \\
1433\end{array}$ & $\begin{array}{l}1556 \\
1433\end{array}$ & $\mathrm{C}=\mathrm{C}$ Aromatic \\
\hline 4 & 1739 & 1739 & 1739 & $\mathrm{C}=\mathrm{O}$ Carbonyl \\
\hline 5 & 2970 & 2970 & 2970 & Asymmetric C-H Alkane \\
\hline 6 & 3414 & Tidak Terdeteksi & Tidak Terdeteksi & Stretching O-H Hydroxyl \\
\hline 7 & Tidak Terdeteksi & 2361 & 2361 & $\mathrm{C} \equiv \mathrm{C}$ alkynes \\
\hline
\end{tabular}

Sumber: Tamunaidu, 2011 
Hasil FTIR pada Gambar 2 dan Tabel 1 menunjukkan adanya ikatan $\mathrm{C}-\mathrm{O}, \mathrm{C}=\mathrm{O}, \mathrm{C}-\mathrm{H}$, dan $\mathrm{O}-\mathrm{H}$ menunjukkan bahwa ikatan tersebut berasal dari senyawa selulosa, hemiselulosa, dan lignin (Sreekala, 1997). Selain itu, terdapat ikatan aromatik yang menunjukkan terbentunya graphite (Rodriguez, 1998).

\subsection{Analisis X-Ray Diffraction (XRD)}

Pengujian XRD dilakukan untuk mengetahui fasa yang terbentuk pada masing-masing sampel. Pengukuran uji XRD dimulai dari $10^{\circ}$ hingga $90^{\circ}$ pada sudut $2 \Theta$. Pola diffractogram XRD pada arang nipah tanpa aktivasi potassium hydroxide $(\mathrm{KOH})$ menunjukkan peak sudut $2 \Theta$ sebesar $31^{\circ}, 38,3^{\circ}$, dan $50^{\circ}$. Pada peak sudut $2 \Theta$ tersebut menunjukkan adanya potassium chloride $(\mathrm{KCl})$. Sedangkan, peak sudut $2 \Theta$ sebesar $26^{\circ}$ dan $45,3^{\circ}$ menunjukkan adanya graphite (Yola, 2019). Kemunculan fasa graphite pada pengujian XRD didukung oleh adanya gugus fungsi aromatic pada hasil pengujian FTIR. Arang nipah yang tidak diaktivasi menunjukkan adanya senyawa impuritas berupa potassium chloride $(\mathrm{KCl})$. Hal ini disebabkan oleh proses karbonisasi yang hanya mencapai pada temperatur $400^{\circ} \mathrm{C}$. Sedangkan, senyawa potassium chloride $(\mathrm{KCl})$ memiliki melting point sebesar $770^{\circ} \mathrm{C}$ sehingga senyawa potassium chloride $(\mathrm{KCl})$ masih terdapat didalam arang. Setelah dilakukan aktivasi dengan potassium hydroxide $(\mathrm{KOH})$, senyawa impuritas berupa potassium chloride $(\mathrm{KCl})$ menghilang (Yola, 2019) yang ditunjukkan pada Gambar 3. Pada peak sudut $2 \Theta$ sebesar $20^{\circ}$ hingga $30^{\circ}$ dan $40^{\circ}$ hingga $50^{\circ}$ menunjukkan adanya karbon aktif amorf (Jani, 2019). Menurut Riyanto (2019), pola difractogram XRD yang tidak menampilkan puncak-puncak yang tajam dan sudutnya lebar menunjukkan karbon aktif memiliki struktur amorf. Karbon aktif serabut nipah memiliki struktur semikristalin atau amorf ditandai dengan adanya puncak puncak bidang (002) pada peak sudut $2 \Theta$ sebesar $24^{\circ}$ dan (001) pada peak sudut $2 \Theta$ sebesar $42^{\circ}$. Bidang tersebut menunjukkan karakteristik karbon aktif amorf dengan cincin karbon yang menumpuk secara tidak teratur (Tang, 2012).

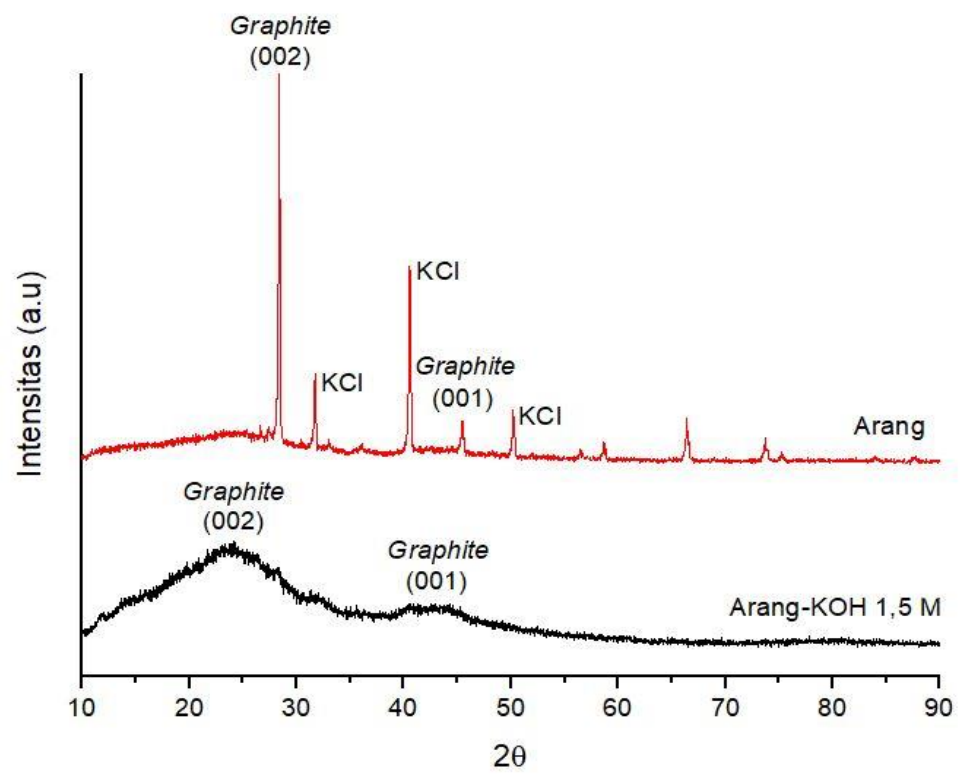

Gambar 3: Hasil Pengujian XRD

\subsection{Analisis Morfologi menggunakan SEM}

Pengujian SEM dilakukan untuk mengetahui morfologi arang yang tidak teraktivasi dan arang yang teraktivasi potassium hydroxide $(\mathrm{KOH})$. Selain itu, pengujian ini dilakukan untuk mengetahui adanya pori-pori yang terbentuk pada sampel. Menurut Tan (2007), melaporkan bahwa morfologi dari aktivasi arang terdapat pori-pori atau porous yang ada pada permukaan arang. Hal tersebut sesuai dengan hasil aktivasi arang yang dilakukan pada Gambar 4. 


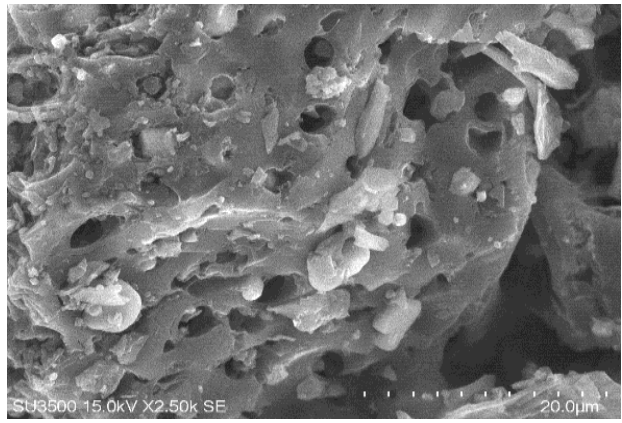

(a)

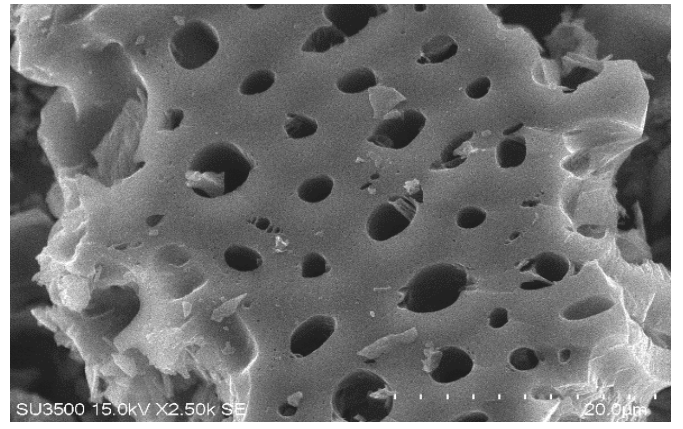

(b)

Gambar 4: Hasil Pengujian SEM (a) Arang tanpa Aktivasi (b) Arang Teraktivasi 1,5 M KOH

Pada Gambar 4 (a) menunjukkan bahwa pori-pori pada permukaan arang tanpa aktivasi potassium hydroxide $(\mathrm{KOH})$ tertutupi oleh tar. Akan tetapi, tar tidak terbentuk pada arang yang telah diaktivasi. Menurut Ahmadpour (1996), melaporkan bahwa penambahan potassium hydroxide (KOH) dapat menghilangkan tar yang terbentuk. Berdasarkan hasil persebaran porositas pada Gambar 5 dan Tabel 2 menunjukkan arang tanpa aktivasi memiliki distribusi porositas lebih rendah dibandingkan dengan arang yang teraktivasi. Dari ukuran porositas, bisa menggambarkan luas permukaan pada arang yang teraktivasi kemungkinan memiliki luas permukaan yang lebih tinggi. Distribusi porositas dapat dipengaruhi oleh adanya sisa-sisa impuritas berupa senyawa potassium chloride $(\mathrm{KCl})$ dan tar. Gambar 3 membuktikan bahwa terdapat senyawa $\mathrm{KCl}$ pada arang tanpa aktivasi. Sedangkan, tar dibuktikan dengan pernyataan dari Ahmadpour (1996).

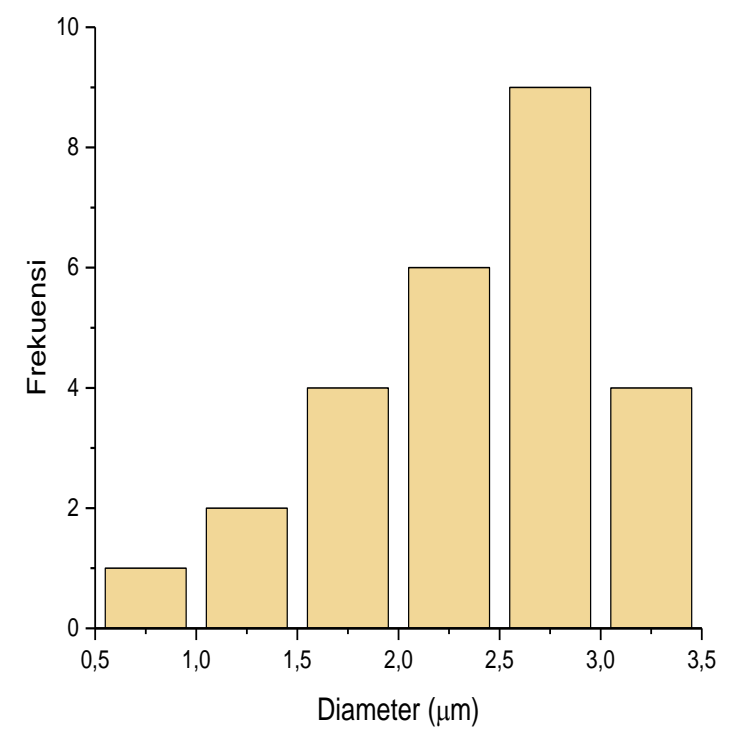

(a)

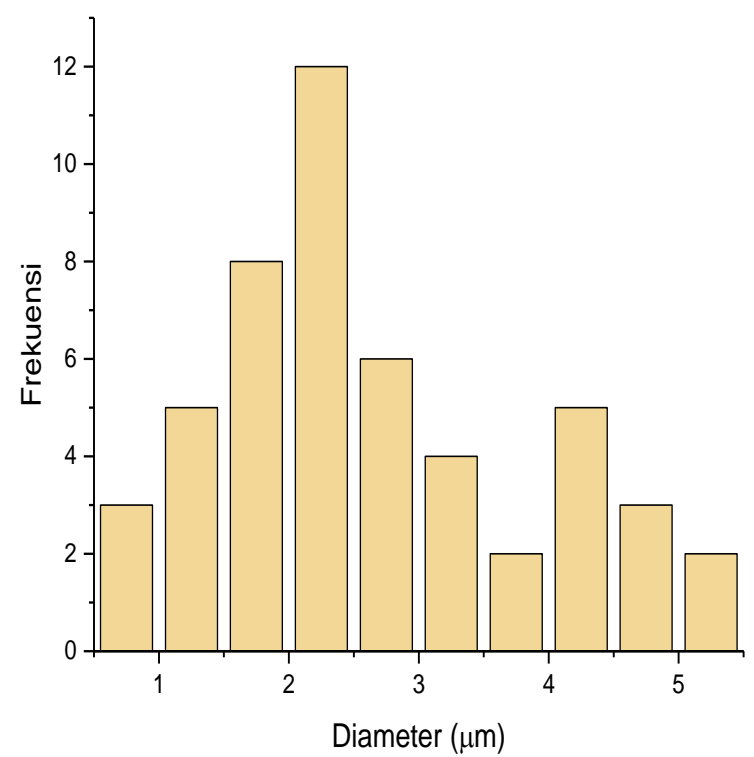

(b)

Gambar 5: Distribusi Ukuran Porositas (a) Arang tanpa Aktivasi (b) Arang Teraktivasi 1,5 M KOH

Tabel 2: Rata-rata ukuran porositas

\begin{tabular}{|c|c|c|}
\hline No & Sampel & Rata-rata Ukuran Porositas $(\mu \mathrm{m})$ \\
\hline 1 & Arang & 2,412 \\
\hline 2 & Arang-KOH 1,5 M & 2,647 \\
\hline
\end{tabular}

\section{Kesimpulan}

Aktivasi karbon serabut nipah berhasil menunjukkan struktur grafit dengan aktivasi secara kimia dengan $\mathrm{KOH}$. Hasil karakterisasi XRD menunjukkan struktur grafit bersifat amorf dengan ukuran rata-rata 
porositas sebasar 2,647 $\mu \mathrm{m} \mathrm{KOH} \mathrm{1,5} \mathrm{M} \mathrm{dan} \mathrm{2,412} \mu \mathrm{m}$ tanpa $\mathrm{KOH}$ sehingga luas permukaan karbon dengan aktivasi $\mathrm{KOH}$ lebih besar dari luas permukaan karbon tanpa $\mathrm{KOH}$.

\section{Ucapan Terima Kasih}

Terima kasih kepada Pusat Penelitian Nanosains dan Nanoteknologi ITB, Lab kimia ITK, Lab material dan metalurgi ITK dan Lab Fisika ITK atas bantuannya meminjamkan beberapa alat karakterisasi.

\section{Daftar Pustaka}

Ahmadpour, A. dan Do, D. D. (1996) 'The preparation of active carbons from coal by chemical and physical activation', Pergamon, Vol. 34, No. 4: 471-479.

Ali, M. Y., Rahman, M. W., Moniruzzaman, M., Alam, M. J., Saha, I., Halim, M. A., Deb, A., Sumi, M. S. A., Parvin, S., Haque, M. A., Khan, M. M. R., dan Khan, M. (2016) 'Nypa fruticans as a potential low cost adsorbent to uptake heavy metals from industrial wastewater', International Journal of Applied Business and Economic Research, Vol. 14, No. 2: 1359-1371.

Cao, Q., Xie, K. C., Lv, Y. K., dan Bao, W. R. (2006) 'Process effect on activated carbon with large spesific surface area from corn cob', Bioresource Technology, Vol. 97, No. 1: 110-115.

Cecen, F. dan Aktas, O. (2011) Activated Carbon for Water and Wastewater Treatment, Weinheim: Wiley-vch

Cheng, S., Huang, A., Wang, S., dan Zhang, Q. (2016) 'Effect of different heat treatment temperaturs on the chemical composition and structure of chinese fir wood', Bioresources, Vol. 11, No. 2: 4006-4016.

El-Hendawy, A. A. (2003) 'Influence of $\mathrm{HNO}_{3}$ oxidation on the structure and adsorptive properties of concobbased activated carbon', Carbon, Vol. 41, No. 4: 713-722.

Foo, K.Y. dan Hameed, B. H. (2011) 'Preparation of activated carbon from date stones by microwave Induced chemical activation: Application for methylene blue adsorption', Chemical Engineering Journal, Vol. 170, No. 1: $338-341$.

Gonzales-Garcia, P. (2018) 'Activated carbon from lignocellulosics precursors: A review of the synthesis methods, characterization techniques and applications', Renewable and Sustainable Energy Reviews, Vol. 82, No. 1: 1393-1414.

Hassen, J. (2017) 'Effect of $\mathrm{KOH}$ ratio on the formation of activated carbon from pressed wood residues', International Journal of Pharmaceutical Sciences and Research, Vol. 8, No. 11: 4875-4880.

Islam, M. S., Ang, B. C., Gharehkani, S., dan Afifi, A. B. M. (2016) 'Adsorption capability of activated carbon synthesized from coconut shell', Carbon Letters, Vol. 20: 1-9.

Lee, M. (2016) X-Ray Diffraction for Materials Research from Fundamentals to Applications, AAP (Apple Academic Press).

Lu, X., Jiang, J., Sun, K., Xie, X., dan Hu, Y. (2012) 'Surface modification, characterization and adsorptive properties of a coconut activated carbon', Applied Surface Science, Vol. 258, No. 20: 8247-8252.

Marsh, H. dan Rodriguez-Reinoso, F. (2006) Activated Carbon, Elsevier.

Muniandy, L., Adam, F., Mohamed, A. R., dan Ng, E. (2014) 'The synthesis and characterization of high purity mixed microporous/mesoporous activated carbon from rice husk using chemical activation with $\mathrm{NaOH}$ and KOH', Microporous and Mesoporous Materials, Vol. 197: 316-323.

Nazaruddin, N., Zein, R., Munaf, E., dan Jin, J. (2014) 'Biosorption of copper (II), lead (II), cadmium (II) and zinc (II) ions from aqueous solution by Nypa fruticans Merr shell on batch method', Journal of Chemical and Pharmaceutical Research, Vol. 6, No. 12: 370-376. 
Noh, J. S. dan Schwarz, J. (1990) 'Effect of $\mathrm{HNO}_{3}$ treatment on surface acidity of activated carbons', Carbon, Vol. 28: $675-682$.

Perkampus, H. (1992) UV-VIS Spectroscopy and Its Applications, Berlin: Springer-Verlag.

Perrich, J. R. (1981) Activated Carbon Adsorption for Wastewater Treatment, CRC Press.

Socrates, G. (2001) Infrared and Raman Characteristic Group Frequencies Tables and Charts Third Edition, New Jersey: John Wiley \& Sons.

Sreekala, M. S., Kumaran, M. G., dan Thomas, S. (1997) 'Oil palm fibers: Morphology, chemical composition, surface modification, and mechanical properties', Journal of Applied Polymer Science, Vol. 66: 821-835.

Sreenivasan, S., Iyer, P. B., dan Iyer, K. R. K. (1996) 'Influence of delignification and alkali treatment on the fine structure of coir fibres (Cocos Nucifera)', Journal of Materials Science, Vol. 31: 721-726.

Tamunaidu, P. dan Saka, S. (2011) 'Chemical characterization of various parts of nipa palm (Nypa fruticans)', Industrial Crops and Products, Vol. 34, No. 3: 1423-1428.

Tan, I. A. W., Ahmad, A. L., dan Hameed, B. H. (2008) 'Optimization of preparation conditions for activated carbons from coconut husk using response surface methodology', Chemical Engineering Journal, Vol. 137, No. 3: 462-470.

Ternero-Hidalgo, J. J., Rosas, J. M., Palomo, J., Valero-Romero, M. J., Rodriguez-Mirasol, J., dan Cordero, T. (2016) 'Functionalization of activated carbons by $\mathrm{HNO}_{3}$ treatment: Influence of phosphorus surface groups', Carbon, Vol. 101: 409-419.

Waseda, Y., Matsubara, E., dan Shinoda, K. (2011) X-Ray Diffraction Crystallography Introduction, Examples and Solved Problems, Berlin: Springer.

Webley, P. A. dan Sun, Y. (2010) 'Preparation of activated carbons from corncob with large specific surface area by a variety of chemical activators and their application in gas storage', Chemical Engineering Journal, Vol. 162, No. 1: 883-892.

Williams, N. E. dan Aydinlik, N. P. (2020) 'KOH ratio effect, characterization, and kinetic modeling of methylene blue from aqueous medium using activated carbon from Thevetia peruviana shell', Chemical Engineering Communications, Vol. 207: 1563-5201.

Xiao, X., Bian, J., Li, M., Xu, H., Xiao, B., dan Sun, R. (2014) 'Enhanced enzymatic hydrolysis of bamboo (Dendrocalamus giganteus Munro) culm by hydrothermal pretreatment', Bioresource Technology, Vol. 159: 41-47.

Yang, T. dan Lua, A. C. (2003) 'Characteristics of activated carbons prepared from pistachio-nut shells by potassium hydroxide activation', Journal of Colloid and Interface Science, Vol. 63, No. 1-3: 113-124. 